\title{
Desventuras e venturas de Suassuna em Portugal
}

\author{
Maria Aparecida Ribeiro ${ }^{1}$ \\ Para Jaime Gralheiro (in memoriam) \\ e José de Oliveira Barata
}

Resumo: Ariano Suassuna tornou-se conhecido em Portugal através das encenações de sua obra. O Auto da Compadecida foi a primeira, e a que mais polêmica acarretou. Mas O Santo e a Porca, bem como A Inconveniência de Ter Coragem também foram apresentadas. Lisboa, Caldas da Rainha, São Pedro do Sul, Coimbra, Ílhavo, São Miguel (Açores) foram palco das encenações feitas por profissionais e amadores, brasileiros e portugueses. A partir da crítica colhida em jornais e na censura feita aos textos compulsados na Torre do Tombo, mostrar-se-á que houve proibições e sucessos, durante o Estado Novo e depois do 25 de abril.

Palavras-chave: Suassuna. Censura. 25 de abril.

Abstract: Ariano Suassuna became known in Portugal through the staging of his works. The Auto da Compadecida (The Play of the Pitiful) was the first, and the one that most controversies caused. But O Santo e a Porca (The Saint and the Sow), as well as A Inconveniência de Ter Coragem (The Inconvenience of Having Courage) were also presented. Lisbon, Caldas da Rainha, São Pedro do Sul, Coimbra, Ílhavo, São Miguel (Azores) were places of staging by professionals and amateurs, Brazilian and Portuguese. From the criticism collected in newspapers and in the censorship made to the texts examined in the Torre do Tombo (The Portuguese National Archive), it will be shown there was prohibitions and successes, during the Estado Novo and after April the 25th.

Keywords: Suassuna. Censorship. April 25th.

Resumen: Ariano Suassuna a été connu au Portugal à travers les mises en scène de son oeuvre. Le "Auto da Compadecida" a été la première et celle qui a provoqué plus de polémique. Mais "O Santo e a Porca" et "A Inconveniência de Ter Coragem" ont aussi paru sur le plateau. Lisboa, Caldas da Rainha, São Pedro do Sul, Coimbra, Ílhavo, São Miguel (Açores) ont été les lieux des représentations, faites par des professionnels et des amateurs, brésiliens et portugais. A partir des critiques parues

1 Doutora em Letras pela Universidade Federal do Rio de Janeiro (UFRJ), ex-diretora do Instituto de Estudos Brasileiros, da Universidade de Coimbra (Portugal) é, atualmente, Professora convidada com Agregação da Faculdade de Letras da Universidade de Coimbra.

Este artigo está licenciado sob forma de uma licença Creative Commons Atribuição 4.0 Internacional,

que permite uso irrestrito, distribuição e reprodução em qualquer meio, desde que a publicação

original seja corretamente citada. https://creativecommons.org/licenses/by/4.0/deed.pt BR.

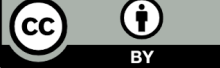


dans les journaux et de la censure faite aux textes, consultées à la Torre do Tombo (Archives Nationales),on montrera qu'il y a eu des interdictions et des succès, pendant l'État Nouveau et après le 25 Avril.

Palabras-clave: Suassuna. Censure. le 25 Avril.

\section{Proposta}

É sabido que Ariano Suassuna não viajava de avião, embora tivesse sido obrigado a usá-lo para ir ao Rio de Janeiro, a fim de receber o fardão da Academia Brasileira de Letras. A Portugal chegou, como todo dramaturgo gostaria de chegar: através das encenações de sua obra. $O$ Auto da Compadecida foi a primeira, e a que mais polêmica acarretou. Mas O Santo e a Porca, bem como A Inconveniência de Ter Coragem também foram apresentadas. Lisboa, Caldas da Rainha, São Pedro do Sul, Coimbra, Ílhavo, São Miguel (Açores) - palco das encenações feitas por profissionais e amadores, brasileiros e portugueses.

A partir da crítica colhida em jornais e das anotações nos textos censurados, compulsados na Torre do Tombo, mostrar-se-á que, se houve cortes e proibições - uma vez que o contexto português foi durante muito tempo dominado pela Censura, com o público e os críticos formados/ formatados nesse ambiente - também houve sucessos. Será também revelada a vitalidade da obra de Suassuna, depois da "Revolução dos Cravos".

\section{Cacilda Becker e a Compadecida em Portugal: A recepção aos artistas}

A primeira peça de Ariano apresentada em Portugal foi o Auto da Compadecida, pela então recém-constituída Companhia Cacilda Becker. 
A 14 outubro de 1959, chegava ao Cais da Rocha Conde de Óbidos, a bordo do navio Vera Cruz, o grupo de atores, e, conforme notícia do Diário da Manhã (1959, s/p), jornal de Lisboa, "Cacilda Becker e o seu teatro tiveram calorosa recepção": foram "carinhosamente, tão carinhosamente" recebidos que "a grande atriz estava visivelmente comovida". A bordo já haviam sido entregues a Cacilda ramos de flores, mas, em terra, ela recebeu outros: de Augusto Mariano, gerente do Tivoli; de João Villaret, o famoso diseur; da atriz brasileira Maria Della Costa, de seu marido e dos atores da companhia da colega e compatriota; de Alma Flora, atriz portuguesa que vivera no Brasil. Cacilda afirmava que o Auto da Compadecida era considerada pelos intelectuais brasileiros "como das mais representativas do Teatro brasileiro" e, por isso, a escolhera para estrear no palco do Tivoli. E acrescentava que a vinda de sua Companhia se enquadrava "perfeitamente no intercâmbio cultural entre Portugal e Brasil, e é de molde a tornar ainda maior a amizade que une os dois povos" (DIÁRIO DA MANHÃ, 1959, p. 6).

No dia seguinte, uma nova notícia também no Diário da Manhã. Sob a manchete "Cacilda Becker apresentou à Imprensa os artistas de sua Companhia", informava: "na boîte do Hotel Tivoli", a atriz afirmou que os catorze atores apresentariam sete peças teatrais, "em vários espetáculos a realizar em Lisboa [...] e durante uma digressão [...] pelo país" (DIÁRIO DA MANHÃ, 1959, p. 4).

Uma dessas peças era o Auto da Compadecida. Presentes na boîte do Hotel Tivoli, estavam nessa ocasião, além de outras pessoas não nomeadas pelo jornal, o mais antigo crítico teatral, Gustavo de Matos Sequeira, a quem Cacilda brindou; o Dr. Baena Soares, adido cultural da Embaixada do Brasil; os Srs. Alarico Silveira e Jorge Pais de Carvalho, 
respectivamente primeiro e segundo secretários da nossa Embaixada em Portugal.

\section{A censura}

Quem consulta, na Torre do Tombo, o exemplar do Auto da Compadecida que foi analisado pela censura portuguesa (um exemplar do livro impresso pela Agir, com o registro 1899, de 1/9/1959, PT/TT/SNIDGE/1/5899), para que Cacilda pudesse levá-lo ao palco português, vê que o espetáculo foi liberado para "adultos, maiores de 17 anos"2. Mas também observa que o lápis da censura não riscou muita coisa; sublinhou apenas estas passagens da introdução de Henrique Oscar:

A linguagem desabrida não deve chocar ninguém. É das personagens e o ambiente retratado. Em Gil Vicente encontramos coisas piores. Com expressões por vezes rudes e outras pitorescas o autor conseguiu um diálogo eminentemente teatral, vivo e saboroso, colorido e descritivo, popular sem ser vulgar e paradoxalmente literário, nada tendo de precioso e alantejoulado. E essa pseudogrosseria e o jeito direto de indicar situações ou comentá-las não lhe tiram o sentido cristão que lhe encontramos.

O próprio autor [...] reafirmou o sentido católico da mesma.

A apresentação das figuras de modo um tanto caricatural mão nos deve fazer incidir em equívoco. O tom é o da peça e note-se - dele são excluídos o Cristo e Nossa Senhora.

O sentido moralizante, moralizante o ponto de vista cristão da obra, está, aliás, presente tanto na sua linha geral, como em inúmeros de seus pormenores, que não seria possível evocar aqui. É lógico, porém, que não contém profundas discussões teológicas, nem faz propriamente apologética, o que seria

\footnotetext{
${ }^{2}$ Também observa que, na informação constante sobre o documento (PT/TT/SNI-DGE/1/5899), consta que a peça foi aprovada com cortes, para ser apresentada pela Companhia Brasileira de Cacilda Becker e em 1964, por Luís de Matos Monte Empina, no Porto.
} 
absurdo. O seu apostolado é feito através da sugestão de um espírito cristão, de uma visão cristã da vida, apresentada com a simplicidade do espírito popular, da fé simples, sem complicações, do povo, quase sempre a mais autêntica (OSCAR apud SUASSUNA, 1957, p. 11 e 12).

Se for bem observado, parece que o texto de Henrique Oscar serviu para explicar aos censores o texto da peça, o que deve ter sido reforçado pelos textos incluídos pelos encenadores como entreatos. Destinados ao público esses entreatos como que colocam em verso as principais ideias da apresentação do livro escrita por Henrique Oscar, inclusive o exemplo do bispo Cauchon, que levou Joana D'Arc à fogueira. O primeiro entreato (não foi possível saber se dito por um ator ou projetado numa tela), onde é reafirmado o catolicismo do autor, lembra que tudo é teatro, que o assunto da peça é o bem que deveríamos fazer e o mal que todos nós praticamos; que o caso do mau padre não é a regra ${ }^{3}$. Já o segundo entreato (cuja forma de apresentação o original consultado na Torre do Tombo também não registra) faz a defesa da peça e do catolicismo de seu autor ${ }^{4}$.

\footnotetext{
3 "Findo este quadro de loucos/narrado por um jogral/ todos já puderam ver/ e ninguém levou a mal/pois tudo aqui é teatro,/ é mentira textual,/tudo é fato exagerado/tudo é caricatural,/tudo é sério brincando,/é gravemente banal./Não é uma apologia/nem lição teologal:/é simples peça de exemplo/num retrato parcial / o autor vem aqui dizer: /do modo mais fraternal/eu me incluo no meu rebanho/e sua chaga geral/Sou igual ao Grilo e ao Padre,/tudo aqui é meu igual/ a mulher viciosa e adúltera/é minha irmã lateral:/assumo meus personagens / no seu ato mais boçal / das mentiras de Chicó / a enterro de animal. / $E$ até cachorro magro, / sujo do pó bestial/é meu irmão, pois morreu./ $E$ eu, ai de mim, sou mortal./A peça é de intenção clara/seu assunto é o bem e o mal / o que todos nós fazemos; / a diferença frontal / entre o que devemos ser / e a maldade do geral. / Se nela aparece o padre/ torpe, covarde, venal/isto não é o que se diga/ que este caso é o caso normal./É o caso particular,/triste, penoso, brutal./Sou católico./Não falo/contra a Igreja total, / Santa Mãe, Casa de todos / No Advento ou no Natal, /seja no pó da Quaresma/seja no fogo Pascal./Esta é a Igreja de Cristo,/a Igreja Sacramental/a que pertenço e onde vivo/abrigado em seu curral,/com a chaga dos meus pecados/com a minha fé integral./E se com as armas do riso/desmoralizo o que é mal/é que tenho o amor por firma/e a esperança por aval." (SUASSUNA, 1957 , p. não numerada, acrescentada pela encenadora).

4 "Aqui, respeitável público/já ouço uma acusação: / — Então um autor católico / cria a maior confusão / exibindo em sua peça / um bispo mau e ladrão? / Nem ele ama a sua Igreja/ nem é peça de cristão/ Pergunto por minha vez:/—Será que aí é só invenção?/ nõ existem bispos ruins?/Neles tudo é perfeição? / São todos puros e santos? / Desgraçadamente, não./ Nem nossa Igreja é de puros: / todos nela têm seu chão./ Quem bem ama, bem castiga/ao povo do seu
} 
O lápis da Censura, como se disse acima, riscou muito pouco. E, em alguns casos, apenas sugeriu uma ou outra mudança de palavra. Vejamos: quando, na fala do Palhaço é anunciado o "julgamento de alguns canalhas, entre os quais um sacristão, um padre e um bispo", vem anotado à margem do exemplar entregue para exame: "indivíduos? pecadores?" (SUASSUNA, 1957, p. 25), numa espécie de sugestão do censor para uma troca de vocábulo.

Eliminada foi a palavra concílio, quando o Bispo diz "Vamos reunir o concílio"5, ao ser informado de que o sacristão acompanhou o enterro do cachorro, proferindo algumas palavras em latim (SUASSUNA, 1957, p. 86). Também foram censurados os momentos em que eram citados artigos do Código Canônico, para justificar as ações: do Bispo, quando declara que o enterro do cachorro em latim é proibido (SUASSUNA, 1957, p. 83) e quando desdiz essa mesma afirmação (SUASSUNA, 1957, p. 100); do Sacristão, quando João Grilo diz que ele agiu bem enterrando o cachorro em latim, e lhe dá um envelope com dinheiro (SUASSUNA, 1957, p.100-101). Ou então aqueles períodos em que um representante da Igreja cedia descarada e declaradamente ao poder. É o caso do Padre que, ao saber que o cachorro era de Antônio Morais, "desfazendo-se em

cordão/ Seja ao pai ou seja ao filho/ que se imponha a correção./Para mim, um bispo é algo / de tão grave provisão, / que me dói ver um ligado / nas cordas da danação. / Neste assunto, eis o pior: madureza cega / que o diabo empresta ao cristão. / Na França, o bispo Cauchon, / malvado cruel, truão, / foi tão servil ao poder / nenhum quinhão; / ela ensinava e ensina / com a maior precisão / a caridade e a justiça / na verdade do perdão / Quem quiser que eterna acusação / o bispo que antecedeu / o de minha narração / era um santo, o que, na peça, / repito sem omissão./ E o frade? Será que viram/que ele tem por seu brasão/uma alegria de santo,/sem jaça, mancha ou borrão?/Notaram no cangaceiro/uma estranha hesitação / que o deteve, por instinto, / na hora da execução, / como se visse no frade / a força da mansidão,/ toda a pureza que havia/em seu manso coração?/Viram que ele é desprezado/pelos maus, sem distinção/exatamente naquilo/que fez dele um bom cristão / - a doçura franciscana / que ele herdou do seu padrão / São Francisco Bernardone / nosso pai e nosso irmão?/Assim, para três patifes - bispo, padre, sacristão - / eu pus na peça dois santos:/ não é pouco, é de razão/ante este pobre rebanho / decaído e em ascensão./ Prouvesse a Deus que no mundo/fosse a mesma proporção! (SUASSUNA, 1957, p. não numerada, acrescentada pela encenadora). $5 \mathrm{O}$ censor anotou à margem: "Tirar só o concílio". 
sorrisos", diz: "Zangar nada, João! Quem é um ministro de Deus para ter o direito de se zangar? Falei por falar, mas também vocês não me tinham dito de que era o cachorro!" (SUASSUNA, 1957, p.35). A oração adversativa, que revela o real motivo da mudança de atitude, é eliminada pelo lápis censor. Ou o caso do Bispo quando é informado de que o cachorro deixou seis contos para a Diocese: a Censura apenas deixa que ele comente "É por isso que eu digo que os animais também são filhos de Deus”, cortando a observação “Que animal interessante! Que sentimento nobre!" (SUASSUNA, 1957, p.85).

Também são cortados os trechos de diálogo entre João Grilo e Chicó, falando do desejo do primeiro em vingar-se do padeiro e da mulher, pelo mal que lhe fizeram. O lápis censor retira a seguinte afirmação de João Grilo: "Mas fiz esse trabalho com gosto, somente porque se tratava de enganar o padre. Não vou com aquela cara" (SUASSUNA, 1957, p. 38). Também corta a fala em que Chicó busca reiterar a antipatia do amigo pelo sacerdote: "Com qual? Com a do padre?" (SUASSUNA, 1957, p.38). Para que não haja perda de sentido, e para atenuar a antipatia de Grilo pelo padre, também é retirado o trecho em que João responde "Com as duas", e censurado o "com o padre", quando ele explica com quem está "acertando as contas" (SUASSUNA, 1957, p. 38).

Quando Antônio Morais informa que seu filho "não quer ir para o Recife sem a bênção do padre" porque "Tem uma verdadeira mania de igreja" (SUASSUNA, 1957, p.44), o lápis do censor suprime esse último trecho.

O diálogo entre João Grilo e a Mulher do Padeiro, quando aquele lhe pede que escreva "Bispo e Padre", no envelope que contém o 
dinheiro, e explica que "o bispo também teve que entrar no testamento" (SUASSUNA, 1957, p.92), vem cortado, mas ou o censor mudou de ideia ou um segundo censor não encontrou razão para o corte. Assim, ao lado dos riscos, está escrito "Pode ficar".

A mais interessante de todas anotações feitas pelos censores está quando Severino chega à igreja. São cortados: o desmaio do Bispo; a observação irônica de João Grilo com relação a ele: "Que grande administrador!"; a pergunta de Severino: "O que é isso que está aí deitado, é algum cônego?; a informação presunçosa do Bispo: "Bispo!"; parte da resposta de Severino: "Ótimo"); o novo desmaio do Bispo, que apenas fica a dizer "Ai!"; o pontapé que Severino dá no Bispo e a observação que o acompanha: "Levante-se e deixe de chamego. Xiii... que comigo não pega” (SUASSUNA, 1957, p. 107-108). Ao lado dos cortes, como que a justificá-los, o censor escreveu: "Retirar, senão [ilegível] demasiadamente o padre" (SUASSUNA, 1957, p.25).

\section{A crítica nos jornais}

Cacilda e seus atores seguiram, claro, o roteiro aprovado pela Censura. Poder-se-ia perguntar: e aí? O público aprovou? E a crítica?

A partir de notícias fornecidas pela UPI, o público carioca lia no Diário de Notícias (1959, s/p) de 23 de outubro a seguinte manchete: "Assustada Lisboa com a 'Compadecida”. E esta notícia:

Lisboa, 22- A representação da obra "Auto da Compadecida", do autor brasileiro Ariano Suassuna, provocou aqui uma controvérsia religiosa. O jornal católico "Novidades", órgão do Arcebispado, diz que tem recebido numerosas cartas de protesto de "pessoas de responsabilidade" contra a obra que 
está sendo apresentada aqui pela companhia de Cacilda Becker, subsidiada pelo governo. "Auto da Compadecida" que foi saudada pela crítica como a melhor obra do moderno teatro brasileiro, trata de um tema aparentemente anticlerical, mas no terceiro ato o autor expõe sua doutrina religiosa. Em sua crítica, afirma "Novidades" que considerava a obra adequada para os católicos com base sólida na doutrina, mas reconheceu que prejudicaria os outros católicos e causaria má impressão entre os não católicos.

\section{Pode fazer mal}

O Diário da Manhã (1959, s/p) expressou sua preocupação pelo fato de que a peça venha alimentar o anticlericalismo.

Esta peça - diz "Novidades" - apesar das qualidades construtivas que lhe não faltam, pode fazer mal a certo público: os católicos timoratos e escrupulosos na visão de todos os pormenores, e os ímpios, ou de má-fé contra a religião e os homens da igreja. Não admiramos que alguns católicos sinceros se escandalizem com a obra de Suassuna, cheia daquelas aparentes irreverências que toda linguagem popular possui, sobretudo se não atentarem para a essência do drama e se fixarem no que lhe apresenta de picaresco, de rudeza primitiva e de acre sabor local.

Aos não católicos, só os move a malícia, e, como não entenderão o terceiro ato em que tudo se explica e sublima, irá a tentação de se quedarem no aspecto crítico do primeiro.

O Diário da Manhã publicou um artigo de Gustavo de Almeida, o qual diz "O que eu conheço é o público português e estou a vê-lo delirante na primeira parte: a anticlerical... É pobre de doutrina para não compreender a segunda..." (DIÁRIO DE NOTÍCIAS, 1959, p. 2).

Que grande deturpação! Os leitores devem ter pensado que a peça foi um fracasso. Mas nada disso. 
Nem o Diário da Manhã nem o Novidades mostram "Lisboa assustada" com a peça de Suassuna. Tampouco apontam qualquer “controvérsia religiosa". O Novidades (1959, p. 2) noticia, sim, "cartas de protestos de pessoas de responsabilidade”. Mas a ordem dos fatores, neste caso, altera o produto, pois não se trata de Matemática, mas de Língua Portuguesa, e, melhor dizendo, de Retórica. Antes de mencionar essas cartas, o articulista afirma, numa "Nota Preliminar", que o "Auto da Compadecida se destina a um público de católicos praticantes e esclarecidos" e vê, na fala do Palhaço, a sinceridade do autor: "é o amor a seus irmãos na Igreja que o faz pôr a nu defeitos, não como quem está de fora, mas como quem está de dentro, compartilhando da dor e implorando que a Misericórdia os limpe" (NOVIDADES, 1959, p. 2).

Como que defendendo Suassuna das críticas contidas nas cartas que referiu, o articulista, que se assina R. M., lembra a necessidade de “serem nobres as atitudes de quem está na plateia”. E é essa plateia que ele analisa, pensando que: "os não católicos, se os mover a malícia, e como não entenderão o terceiro ato em que tudo se explica, virá a tentação de se quedarem no aspecto crítico do primeiro" (NOVIDADES, 1959, p. 2). E acrescenta: "e poderão até achar anticlerical uma peça em que, afinal, Nossa Senhora não só intercede com êxito junto aos pecadores, mas é a primeira em defesa do clero" (NOVIDADES, 1959, p. 2). Ora o que se observa nas palavras do articulista é uma análise do público; não uma crítica à peça.

E o que R. M. viu foi "uma plateia rendida e conquistada" e uma "afortunada noite para os amantes de teatro", porque era 
só o que é puro e conta, [...] Era como se se assistisse ao nascer de uma era nova na história do Teatro! (NOVIDADES, 1959, p. 7).

Ao lado dessas observações sobre a reação do público, o crítico tecia inúmeros elogios à atuação da Companhia Cacilda Becker, destacando o trabalho de cada um dos atores.

Com esses elogios, estava de acordo Goulart Nogueira, crítico do Diário da Manhã:

A encenação deste espetáculo, assinada por Cassilda Becker, é justíssima e duma limpidíssima beleza. Os simples, ingénuos, sábios cenários e figurinos de Malgari Costa; a movimentação plena de leveza, graça, delicado sentido cómico, expressão e afinadíssimo rigor; a iluminação sublinhando o clima com oportunidade e discrição; a perfeição dos mimos e seus efeitos (todos originais? Não haverá, por exemplo, um encontrado em Jouvet?); a frescura, a pureza, o processo de dar, através da marcação, uma comicidade lírica; a serenidade com que tudo decorre e se resolve; o modo com que se encontra uma linguagem popular de toda a peça; - merecem um prolongado aplauso, um agradecimento emocionado. [...] Das interpretações dos atores, destaquem-se Benedito Corsi, Walmor Chagas, Cleyde Jaconis, Rubens Teixeira, Cassilda [sic] Becker, mas louvem-se todos [...] (DIÁRIO DA MANHÃ, 1959, p. 6).

Mas o jornal carioca (Diário de Notícias) não os transcreve. Aliás, até troca o nome do crítico, chamando-o Gustavo Almeida.

Goulart Nogueira, em seu artigo "Auto da Compadecida de Adriano [sic] Suassuna, pelo teatro Cassilda [sic] Becker no Tivoli", começa por chamar a atenção "para a relutância dos portugueses para a pureza dos gêneros chamados clássicos", fazendo também uma crítica ao fato de se querer filiar a peça apresentada pelo grupo brasileiro ao medievalismo e a Gil Vicente, pois ele vê nela não só uma filiação aos mistérios, milagres, moralidades, devoções, entremeses, farsas e diabruras, mas também aos autos do "século do oiro", a Plauto, 
a Aristófanes e a manifestações folclóricas. Mas, apesar de ser contra a filiação que pretendem dar à peça, afirma que ela é "maravilhosa" e indica-a "como exemplo aos novos autores de Portugal e Brasil", concluindo "Isto, sim, é modernidade e é tradição, é realismo e "nacionalismo", transpondo-se ao plano da arte e da poesia e do teatro.” (DIÁRIO DA MANHÃ, 1959, p. $6)$.

\section{2: a Compadecida vence um concurso}

Em 17 de julho de 1962, o jornal das Caldas da Rainha - terra famosa por suas águas termais, por seus doces e também por sua cerâmica (em especial a criada por Rafael Bordalo Pinheiro) - o Conjunto Cénico Caldense (CCC) noticiava na sua coluna que entraria no Concurso de Arte Dramática do SNI, encenando, no dia 27 de julho, o Auto da Compadecida. E complementava a informação dizendo das qualidades da peça e das hesitações e dificuldades do grupo ao montá-la:

[...] com a qual enriqueceremos sem sombra de dúvida o nosso reportório. E com ela teremos oportunidade de trazer até ao público - e a nós próprios - a mensagem do Teatro Brasileiro, cujas características nacionais não deixam de ter, pela universalidade dos temas, aquela projeção necessária para servir a outros povos.

Peça difícil, trabalhosa, com muitos problemas a resolver, o "Auto da Compadecida" será - se inteiramente conseguido mais um grande passo em frente na história do CCC. E se repararmos que sete dos seus catorze intérpretes masculinos são estreantes no elenco do Conjunto, teremos aí uma justa medida para avaliar as redobradas dificuldades - e também do desejo de trabalhar em profundidade, buscando novos elementos que prossigam uma atividade que precisa continuadamente de renovar-se. Esta é, desde já a melhor experiência que recolheremos da representação da farsa, pois é ela que nos dá a oportunidade de repetir futuras experiências. Entre os vários casos que tivemos de resolver, um dos que exigiu mais cuidado foi a maneira de "dizer" a peça. Escrita por um brasileiro, tendo um tema popular - está ela recheada de "brasileirismos", característicos da maneira de dizer do povo 
do grande país de Além-Atlântico. Iríamos tentar imitar a pronúncia, mas falseando-a inevitavelmente? Ou seria mais honesto, embora respeitando a sintaxe - que é muito da graça do "Auto" - representá-la com a pronúncia portuguesa? Foi por esta alternativa que se decidiu o nosso Conselho Técnico, na certeza de que ela melhor servirá a verdade da nossa interpretação (GAZETA DAS CALDAS, 1962, p. 5).

A notícia falava ainda das dúvidas de quem coloca em cena qualquer peça, sejam elas originadas pela própria capacidade do encenador e dos atores ou pela empatia do público:

Não sabemos até que ponto o "Auto da Compadecida" encontrará no público aquela receptividade que desejaríamos - e que sucede sempre que acontece Teatro. Como quer que seja, quando o pano abrir para a representação, ali estarão as nossas inquietações, o nosso esforço, a nossa procura de verdade, para as oferecermos a quem as queira viver conosco. E se, no palco, surgir o Teatro com toda a sua magia - então estaremos recompensados (GAZETA DAS CALDAS, 1962, p. 5).

Mas a parte mais importante nas considerações tecidas sobre a peça vinha depois de a "Coluna do CCC" fornecer uma pequena biografia de Suassuna: a peça representava

o aproveitamento de um tema regional elevado à categoria de originalidade. Com Ariano Suassuna temos teatro autenticamente brasileiro [...]. É uma obra impregnada de Nordeste, dos seus problemas dos seres, das alegrias e sofrimentos de um mundo de cristianismo primitivo e por isso mesmo em revolta contra as facilidades sedimentadas no tempo e aproveitadas pelos poderes temporais, tem muito dos antepassados portugueses conservados no sangue e numa tradição viva. Tem muito da crítica (e também da maneira) de Gil Vicente ao clero gozador e aos poderosos, tudo num Compadecimento final de ordem religiosa e humana, que dá, sem dizer expressamente, uma tonalidade, um estremecimento evangélico a este "Auto" de Ariano Suassuna (GAZETA DAS CALDAS, 1962, p. 5). 
A 25 de julho de 1962, a Gazeta das Caldas considerava "extremamente audaciosa" a apresentação pelo CCC da "particularíssima e difícil obra de Suassuna" porque colocaria em cena "14 personagens, nove delas estreantes, com o encargo de interpretarem papéis de grande melindre" (GAZETA DAS CALDAS, 1962, p. 1).

E o mesmo jornal, em 7 de agosto do mesmo ano, trazia manchete que punha nos leitores alguma dúvida sobre o sucesso do CCC com a peça de Suassuna: "O C.C.C. elevou-se, mais uma vez na exibição da Auto da Compadecida, mas não obteve a total compreensão do público caldense". E explicava:

\begin{abstract}
De alguma maneira, havíamos previsto, e até dado a entender no penúltimo número deste jornal, que a escolha da peça de Suassuna para o Concurso de Arte Dramática do SNI constituiria sério problema a enfrentar pelo Conjunto Cénico. As obras de Arte construídas a dentro de determinado meio social, específico e incomum, a crítica de costumes transplantada para o teatro e a invocação de lendas, adágios, conceitos, hábitos e tendências de certos povos supõem, naqueles a quem se dirigem e por parte dos que as personificam, conhecimento relativamente amplo desse meio social, desses costumes e desses povos.

Ora, esse é o caso de "Auto da Compadecida" porque nem os valorosos intérpretes caldenses nem o público das Caldas, aliás cheio de boa vontade, sabem o bastante da vida e das lendas, adágios, conceitos, hábitos e tendências duma pequena cidade gaúcha [sic] do Brasil de hoje (GAZETA DAS CALDAS, 1962, p.1).
\end{abstract}

Apesar das ressalvas feitas e da sua própria confusão situando os gaúchos no Nordeste (o que mostra que ele também se inclui nos desconhecimentos apontados), o articulista revela que a ignorância da assistência não foi barreira para que acontecesse teatro. Mas não dá a conhecer ao leitor o que de fato ocorreu, para a escolha de tal manchete, 
pois não dá detalhe algum sobre a reação do público; apenas comenta a atuação dos atores e elogia o texto de Ariano, como se pode ver:

E se isso não impediu, por forma alguma, que no Cineteatro Pinheiro Chagas, quando ali se apresentou, na noite de 27,0 Conjunto Cénico pela mão de Suassuna, acontecesse teatro, obstou a uma íntima e perfeita comunicação entre o palco e a plateia.

Mas a constância da excelente presença de Paniágua Féteiro, que do primeiro ao último instante dominou o público com as suas qualidades e a sua cultura de ator - e de ator que transcende em muito os limites do amadorismo - e a figura de João Grilo que criou (é o termo) num complexo em que a fala não ficou aquém do gesto nem o gesto excedeu a fala, revelando o intérprete no papel que melhor desempenhou até hoje, não merecem se lhe aponte um único senão.

Mas a concepção de Xicó [sic] (José Joaquim de Sousa) auxiliou também a vencer as dificuldades tão elevada e perfeita se apresentou.

E o bem concebido diálogo entre ambos, que se processa desde que se abre até que se fecha o pano, justifica-se só por si e é, em si mesmo, uma obra de Arte.

Hermínio Maçãs, se é estreante, não o parece tal é o seu sentido de presença, o timbre de voz, a segurança no desempenho dum papel não longo mas difícil.

De Garrido e Maria da Graça Sousa só não se pode dizer o mesmo que dos dois primeiros porque nem a extensão das suas intervenções nem a dureza dos seus trabalhos se comparam às das duas figuras centrais da peça. Do primeiro, porém, como encenador, pode afirmar-se, contudo, caber-lhe lugar de vanguarda dado que era esse, de entre todos, o mais difícil dos postos.

Maria Manuela Gil acusa, entre todos os consagrados, a deficiência mais notória no público, que foi a que apontámos primeiro. Em todo o caso, e naquilo em que há de comum a um determinado tipo de mulher, soube compreender os obstáculos e transpô-los com a habilidade que lhe é peculiar. Luís da Silva Carmona é, de entre os estreantes, uma revelação - promessa de um bom amador.

De resto e dum modo geral as estreias atingiram um nível que não esperávamos elas alcançassem.

José dos Santos Lino só muito raramente soube apresentar-nos as características fundamentais do "Bispo", voluntarioso, severo, dominador. 
Carlos Gil conseguiu, de alguma maneira, transmitir à plateia o objetivo do autor - apresentar um sacristão mais senhor do Templo do que o próprio sacerdote.

A peça de Suassuna apresentava ainda sérias dificuldades na sua temática e na estrutura. Corria-se o risco, ante o espetador desatento, de aparentar irreverência ao que se deve reverenciar, desrespeito ao que merece submissa e filial devoção.

O escritor brasileiro, a pretexto de nos pintar, a tintas de cor viva, o modo de ser de certos, raros, sacerdotes, existentes no país irmão, encarna a figura popular de João Grilo, plena de astúcia, para produzir certas afirmações e evidenciar algumas dúvidas, à primeira vista, sacrílegas. Mas descrevendo uma fórmula primária de conceber a Religião de Cristo e evidenciando confusões que são naturais nas formações rudimentares, Suassuna cria problemas a que logo empresta a melhor solução e culmina a sua obra de Arte com um hino altissonante de louvor a Deus - a Jesus (Manuel) e a Sua Mãe, a Compadecida.

Sabe definir, com o tom cativante e carinhoso do Cristianismo, a aparente antinomia Justiça - Misericórdia.

E quando no palco nos apresenta um Manuel (Cristo) de raça negra logo explica a razão do facto que reside na universalidade do Filho de Deus e do infinito poder da Providência; essa forma traça, aliás simultaneamente, a condenação formal da segregação racial - com referência expressa à América - e o elogio rasgado das civilizações multirraciais de que nós portugueses temos primado.

Estas ligeiras notas servirão tão somente para que o leitor aquilate do alto nível da obra de Arte e, portanto, da arrojada tarefa que a si mesmo se impõe o C. C. C. (GAZETA DAS CALDAS,1962, p.1 e 2).

A verdade é que o Conjunto Cénico Caldense obteria, entre dezenas de grupos amadores de todo o país, o primeiro prêmio no concurso do SNI, como noticiava a Gazeta das Caldas, de 9 de outubro de 1962 (p.1-4). E mais: foi o único concorrente que recebeu três primeiros prêmios: um na categoria A - representação de comédia ou farsa, denominado "Joaquim Almeida”; outro de interpretação masculina da mesma categoria e modalidade, concedido a Carlos Paniágua Féteiro; e ainda um outro, encenação, dado a Carlos Tavares Garrido. Além disso, 
houve menções honrosas para as interpretações de Hermínio Maças do Couto e José Joaquim de Sousa.

Não se pense, porém, que o orgulho estampado no jornal das Caldas se deveu ao fator bairrismo: O Século, diário lisboeta trazia, no dia 1 de outubro de 1962, a seguinte manchete: "Magnífica realização do Auto da Compadecida pelo Conjunto Cénico Caldense, no Teatro da Trindade" (O SÉCULO, 1962, s/p). E, além de classificar como "admirável" a peça de Suassuna, o articulista D. M. parabenizava o Cénico por ter resistido a imitar o sotaque brasileiro, chamando também a atenção de que era aquela, a do CCC, a primeira interpretação portuguesa, pois até então só a brasileira Cia de Cacilda Becker a colocara nos palcos de Portugal.

\section{Figura 1 - O Cénico das Caldas ganha festival com o Auto da Compadecida}

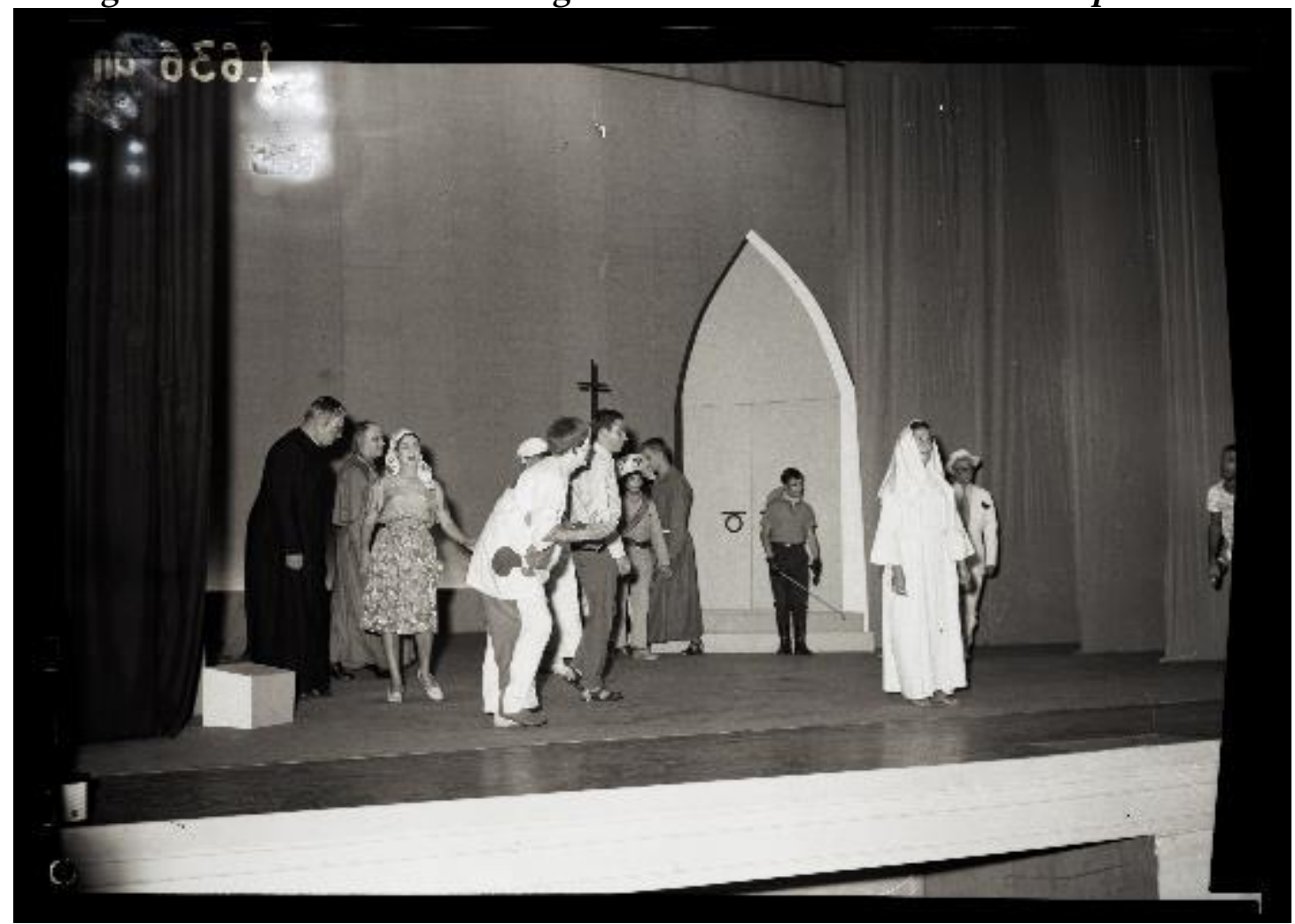

Fonte: jornal O Século álbum 147-1962 AN 30/9/1962 
Cabe ainda acrescentar que concorreram com o Cénico, na fase final, a 30 de setembro de 1962, o Lusitano Clube de Évora e A Família das Zambujeiras. Depois da vitória em Lisboa, o CCC apresentou-se em Coimbra, no Teatro Avenida, com o Auto da Compadecida; o público vibrou, dando vivas às Caldas, enquanto os estudantes arremessavam ao ar suas capas negras.

\section{Anrique da Mota, Gil Vicente, Brecht e três brasileiros}

Em 11 de março de 1967, dava entrada na Censura a peça Mestre Gil. O nome se devia ao fato de ter sido uma montagem destinada às comemorações vicentinas no Rio de Janeiro, que foi representada no Teatro da Exposição Portugal de hoje, sob os auspícios dos Serviços Culturais da Embaixada de Portugal no Rio de Janeiro. Apesar do nome e do objetivo, reunia textos de Anrique da Mota, António José da Silva (o Judeu), Martins Pena, Ariano Suassuna e Brecht. Liberada em 10 de abril, pelo censor Clemente Rogerio, que, como se pode ver no exemplar guardado na Torre do Tombo (ANTT-SNI. DGE - 1/8404), classificou o texto para maiores de 17 anos e marcou, como chama a atenção José de Oliveira Barata (2009, p. 225), o nome de Brecht, a peça foi representada pelo Grupo Cénico da Associação Acadêmica da Faculdade de Direito de Lisboa, dirigida por Luís de Lima, em abril de 1967, na Semana Cultural das Associações de Estudantes de Lisboa. A montagem dos excertos, feita por Domingos Mascarenhas e Luís de Lima, continha notas explicativas. Sobre Gil Vicente, vários dados biográficos; trecho de carta que ele enviou a D. João III sobre o tremor de terra de 1531; suas declarações sobre 
os judeus (antecedidas do que diz o Concílio Vaticano II sobre as religiões não cristãs); etc.

Antecedendo o excerto tirado do Auto da Compadecida, Mascarenhas e Lima escreveram:

Vamos agora pôr em evidência como Gil Vicente se encontra nos grandes autores modernos e contemporâneos. Caso concreto é a conhecida peça Auto da Compadecida de Ariano Suassuna.

Toda a obra descende em linha reta de Gil Vicente.

A estrutura teatral e a composição das personagens de Suassuna são nitidamente vicentinas,

E é vicentina a forma como Suassuna põe N. Sra. e Jesus Cristo... Ou seja a Compadecida e Manuel a contracenar com as outras criaturas.

Há uma cena, até, que parece inspirada na súplica de Cananéia. Perto do final da peça, várias personagens são mortas: um bispo, um cangaceiro, a mulher do padeiro, um sacristão e João Grilo. Uma espécie de Arlequim que é o protagonista. Tal como nos Autos das Barcas, de Mestre Gil, toda essa gente vai ser submetida a julgamento.

Estão presentes Cristo, personificado por Manuel, que surge como alguém de raça negra, e o Diabo, ou seja, o Encourado. João Grilo, vendo que ele e os outros se vão perder, tem uma inspiração: recorre à intervenção da Compadecida (MASCARENHAS \& LIMA, 1967, p. 2).

Os excertos utilizados pertencem à última parte da peça, quando João Grilo e os outros contracenam com Cristo e com a Compadecida.

\section{Malhas que o Império tece: dois na plateia e uma peça memorável}

Sem nenhuma observação ou corte da Censura, como tivemos ocasião de verificar no Arquivo da Torre do Tombo, apoiada por um subsídio de duzentos e noventa e nove escudos e vinte e oito centavos, 
O Santo e a Porca foi encenada no Teatro ABC de Lisboa, pela companhia Teatro do Arco da Velha, entre dezembro de 1970 e junho de 1971.

Figura 2 - Ruy de Carvalho, em O Santo e a Porca, 1971

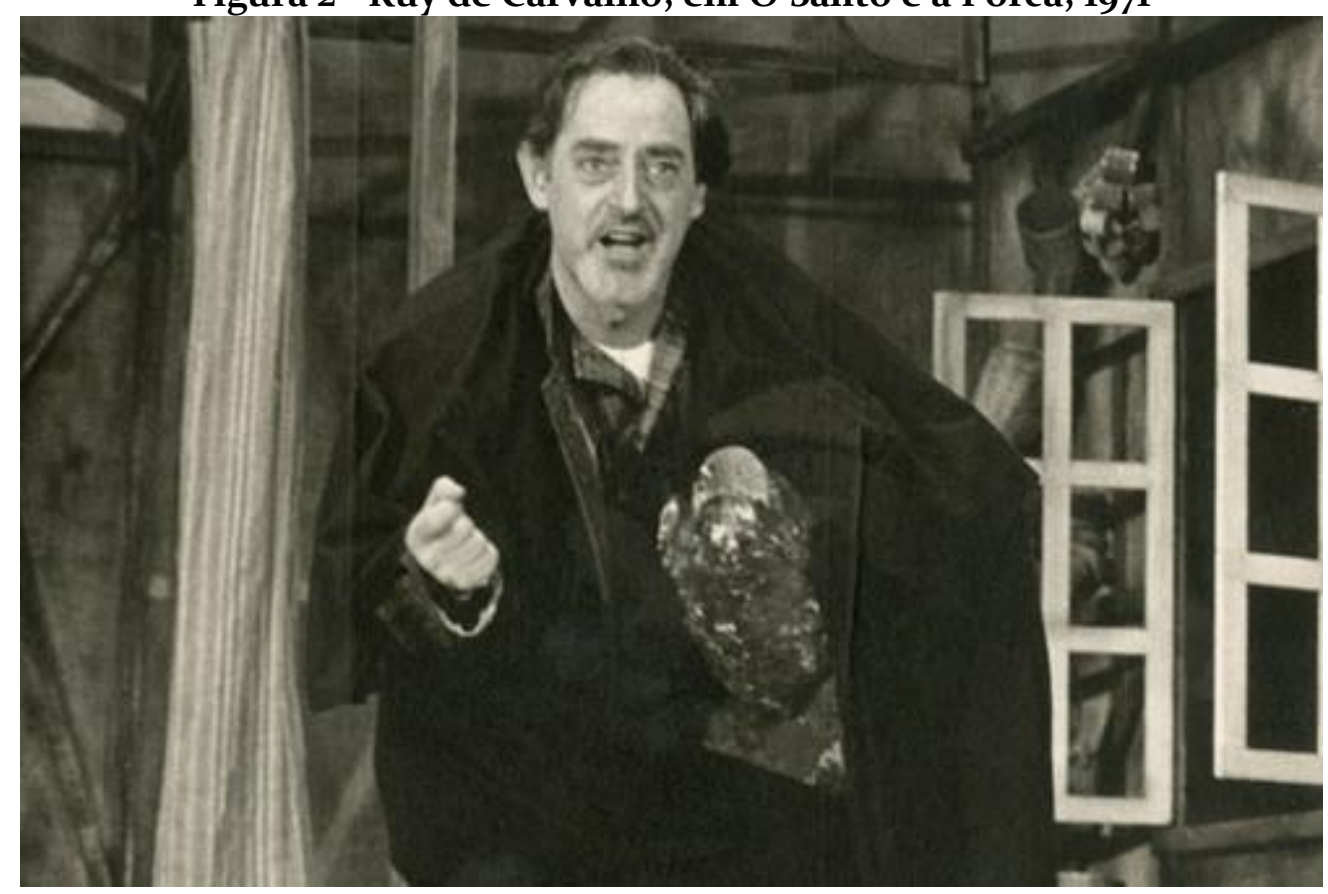

Falando das peças em que mais gostou de atuar, Ruy de Carvalho, renomado ator português, o eterno Rei Lear, já que sua interpretação da personagem shakespeariana o consagrou e se consagrou como imbatível, considerou O Santo e a Porca, uma das peças de sua vida. E por quê?

Depois de encená-la em dois teatros - o ABC e o Laura Alves fê-lo na Academia de Santo Amaro. Esta última apresentação, como declarou o próprio ator, numa entrevista a Adelino Gomes, ficou marcada por um fato curioso:

Acabámos a fazer a peça numa matinée para dois espectadores na plateia. Decidimos fazer o espetáculo porque os que gostam são os que vão. Correu tão bem, tão bem, que tivemos cinco panos! Passados bastantes anos, estava eu no Espaço Lisboa a almoçar com os filhos e a mulher, e vem-me o Abel Cruz, fotógrafo: "Estão ali duas pessoas que te querem dar um beijinho." Eram os dois espectadores. Pais dele. Para mim, não 
há número de espectadores. Aqueles que vão, merecem o nosso trabalho (PÚBLICO, "Oito peças para uma vida", 2007, p.15).

É importante dizer que era Fernanda Alves, uma encenadora cheia de energia, a diretora da peça. Fernanda também dirigiu os Plebeus Avintenses, grupo amador de Avintes, região do Porto, e havia encenado com eles, em 1967, O Santo e a Porca. Com isso, ganharam um prêmio da Embaixada do Brasil.

\section{O Cénico de São Pedro do Sul e o Auto da Compadecida}

Criado no Café Edgard em 1971, por Jaime Gralheiro, António Bica, José Oliveira Barata e Manuela Cruzeiro, e funcionando encostado ao campo de futebol do União Desportiva Sãopedrense, o Cénico Grupo de Teatro Popular de São Pedro do Sul resolveu levar à cena, nesse mesmo ano de sua fundação, o Auto da Compadecida. Foram apresentados sete espetáculos, depois de um ensaio de três meses (primeiro na sede da União Desportiva Sampedrense, no Largo de S. Sebastião; depois, no salão nobre dos Bombeiros Voluntários; e, mais tarde, no Cineteatro, em S. Pedro do Sul, onde a peça estreou, no início de 1972). Depois de três apresentações no Cineteatro, uma em Vouzela, uma em Aveiro, uma em Mangualde e uma em Ribeiradio, havendo ainda outras programadas, a peça foi suspensa pela Censura. O motivo alegado? Os estatutos da União Desportiva Sampedrense não previam a criação de uma seção cultural, lembra Jaime Gralheiro, no texto que publicou no blog da Aldraba.

No entanto, deveria haver outras razões.

António Bica pertencia ao PC; Barata e Manuela Cruzeiro eram simpatizantes do Partido. Gralheiro, então um católico progressista, 
andava em crise religiosa profunda. Discutia seus problemas no Café, com o pároco de São Pedro do Sul, que também frequentava o local.

Num ofício de 11 de novembro de 1971, a Direção dos Serviços de Espetáculos, ao informar ao Cénico como deveria fazer para obter a licença para a apresentação do Auto da Compadecida, comunicava:

[...] informamos que a referida peça não pode ser levada à cena, sem que solicite, a estes Serviços, o ensaio de apuro da referida peça, com a antecedência de 10 dias, indicando o dia, hora e local que o mesmo se efetuará (GRALHEIRO, 2014, p. 1).

Esse ensaio de apuro, por ser normalmente exigido aos grupos profissionais ou aos grupos universitários olhados com reserva, parece ter sido ignorado pelo Cénico, uma vez que não se encontra em seu arquivo cópia de nenhum requerimento com esse pedido.

A peça fez muito sucesso, como documentam fotos da estreia existentes nos arquivos do Grupo, já que, a Tribuna de Lafões, único jornal de São Pedro do Sul, ligado ao regime, nada publicou sobre o assunto. No entanto, em Ribeiradio, o Auto da Compadecida provocou a reação de elementos do clero. Talvez esta - e o fato de haver entre os diretores do espetáculo quem pertencesse ao PC, quem fosse simpatizante das ideias difundidas por ele e quem discutisse publicamente sua crise religiosa - tivessem sido as maiores razões para a proibição do espetáculo. Até porque, àquela época, Igreja e Estado andavam muito juntos.

A Voz de Ribeiradio (1/3/72), um boletim paroquial, estampava sob a manchete “Teatro, Crítica Religiosa ou Demagogia?” a seguinte notícia: 
Vinha fazer teatro com um tema religioso.

Não assistimos, conhecíamos, porém, a peça de uma leitura, há alguns tempos.

O Grupo Cénico Sampedrense é um grupo de amadores que preparou uma peça para representar, como entre nós se tem feito com relativa frequência.

Da atuação nada dizemos por não termos assistido, mas podemos afirmar que também o nosso grupo de jovens executaria essa ou outra peça, com arte, só não seria capaz de vender a cultura teatral a $20 \$ 00$ por pessoa, pois costuma contentar-se com uns $5 \$ 00$ acessíveis às nossas gentes que precisam de ver teatro, mas não têm possibilidades económicas.

Quanto à peça, um auto com um tema religioso, com asneiras, cornos, mulheres de má vida, o demónio, Deus, Nossa Senhora, Padre e Bispo, tudo à mistura, denota o mau gosto e a falta de escrúpulos de quem escolhe uma peça idealizada no Nordeste Brasileiro para ser representada num meio sociorreligioso como é o nosso.

Alguém nos perguntou se teria sido uma exibição teatral ou uma sessão de propaganda eleitoral.

Confesso que não sei responder, pois não tenho o condão de adivinhar as intenções dos outros...

De qualquer maneira, bastantes não gostaram e muitos ao terminar, puderam dizer a brincar: "bem dizia a minha mulher..." (só os que assistiram compreendem) (A VOZ DO RIBEIRADIO,1972, p.1).

É de reparar a ignorância do articulista sobre a cultura brasileira. Desta vez, não se situam os gaúchos no Nordeste, mas ignora-se por completo o quão religioso é o povo nordestino. Por outro lado, chamam a atenção o conservadorismo e a tacanhez da ideia de que só se deve ver aquilo que se conhece. Mais: não há propriamente uma crítica à peça, mas a quem a encenou, seja pela escolha feita, seja porque cobrou ingressos; apesar de o Concílio Vaticano II já ter ocorrido há dez anos, parece não ter chegado ao pároco de Ribeiradio, que não entendeu o sentido da peça, apesar de dizer que a leu. 


\section{Liberdade, Liberdade!}

A partir do 25 de abril, isto é, a partir de 1974, a Censura já não é tão rigorosa. No entanto, Suassuna, ao que parece, só volta a surgir nos palcos portugueses depois do ano 2000. Mas continua na preferência apenas do teatro amador.

Em São Pedro do Sul, o Cénico voltou a encenar o Auto da Compadecida, em 2001-2002. Um tempo em que já não era preciso acompanhar as jovens atrizes até suas casas, como acontecia em 1967, quando da primeira encenação. O elenco era outro: António Santos Pereira (João Grilo); Joaquim Cardoso (Chicó); João Cerveira (Bispo); José Carlos Chã (Padre); Marcus Vinicius (Sacristão); Carla Figueiredo (frade); Paula Silveira (Compadecida); Mário Almeida (Manuel); Zé Correia (Severino de Aracaju); Licínio Oliveira e Juliana Branquinho (Padeiro e sua Mulher); João Carlos Gralheiro (Encourado e Antônio Moraes); Nuno Gomes (Cangaceiro-e Diabo).

Em 2003, o encenador brasileiro Antônio Terra põe no palco o Auto da Compadecida, primeiro num workshop no Open Space Studio (Lisboa); depois, Ribeiro Chaves, proprietário desse espaço resolveu produzi-lo em temporada curta, mas com sucesso, no Teatro Tivoli (Lisboa), em novembro, foi levado à cena no Teatro Amélia Rey Colaço (Oeiras). Pela primeira vez o texto sofreu adaptações: o sertão de Pernambuco virou o vale do Zêzere. Terra manteve o Cristo negro, feito pelo Tiago Justino, brasileiro, que era negro e tomava água de coco. Depois, pelo Projeto Amphiteatrum, Antônio Terra usou a Compadecida numa oficina de teatro, no Teatro Ribeiragrandense (São Miguel, Açores), mais uma vez fazendo adaptações: tornou-se a peça muito 
musical, tocando sanfona; o Nordeste de São Miguel (a parte mais isolada da ilha) ficou sendo o Nordeste brasileiro; o técnico do teatro foi pintado de negro, para poder encarnar Cristo.

Em março de 2005, durante a VII Semana Cultural da Universidade de Coimbra - “Abraço Lusófono”, o grupo Galpão das Artes (Limoeiro, Pernambuco, Brasil), apresentou, por iniciativa do Instituto de Estudos Brasileiros, no Teatro Paulo Quintela (Faculdade de Letras), para 455 espectadores, A Inconveniência de ter Coragem. Muito aplaudidos, esses jovens deram à plateia e com ela viveram uma experiência inesquecível.

Figura 3 - Atores do Galpão das Artes (Limoeiro, Pernambuco) com Maria Aparecida Ribeiro, então Diretora do Instituto de Estudos Brasileiros da Universidade de Coimbra.

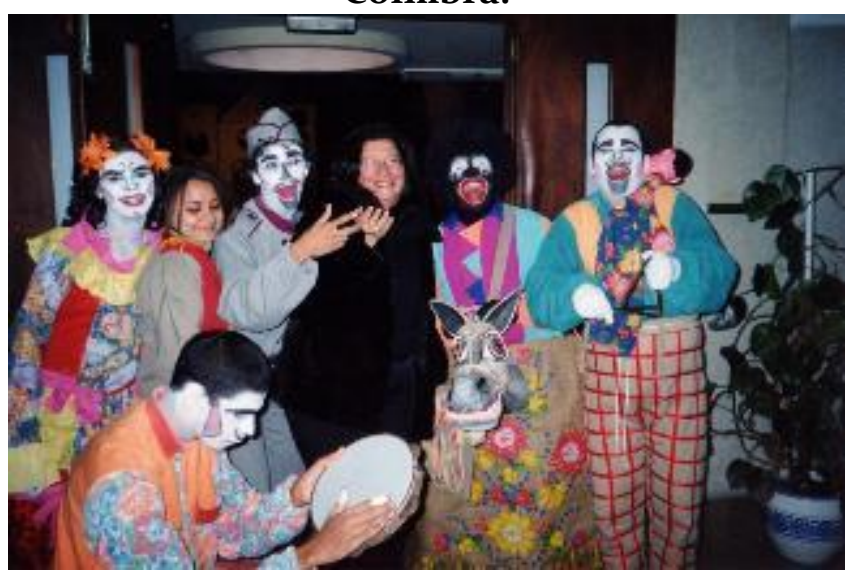

Em 9 de outubro de 2010, o grupo amador Plebeus Avintenses (Avintes, Vila Nova de Gaia) levou ao Teatro Coelima, do Centro Cultural e Desportivo Coelima, instituição sem fins lucrativos, fundada 1966, da conjugação de esforços dos trabalhadores da Coelima Indústrias Têxteis S.A. (Guimarães), O Santo e a Porca, cuja recomendação era "para maiores de 12 anos".

Em 17 de novembro de 2016, o Teatro Micaelense (ilha de São Miguel, Açores) acolheu, durante a $17^{\mathrm{a}}$ edição do JUVEARTE - festival de 
teatro, o Grupo de Teatro Alpendre, que apresentou o Auto da Compadecida, com encenação de Válter Peres.

Em junho de 2017, o Grupo de Teatro Ribalta, na capela das porcelanas Vista Alegre, em Îlhavo (Aveiro), apresentou, em função das festas de Nossa Senhora da Penha de França, com encenação de José Fino, o Auto da Compadecida. Em setembro, será a vez de O Santo e a Porca ser mostrada no Porto, pela Cia Teatral de Ramalde (Porto), sob a responsabilidade do encenador Alfredo Correia.

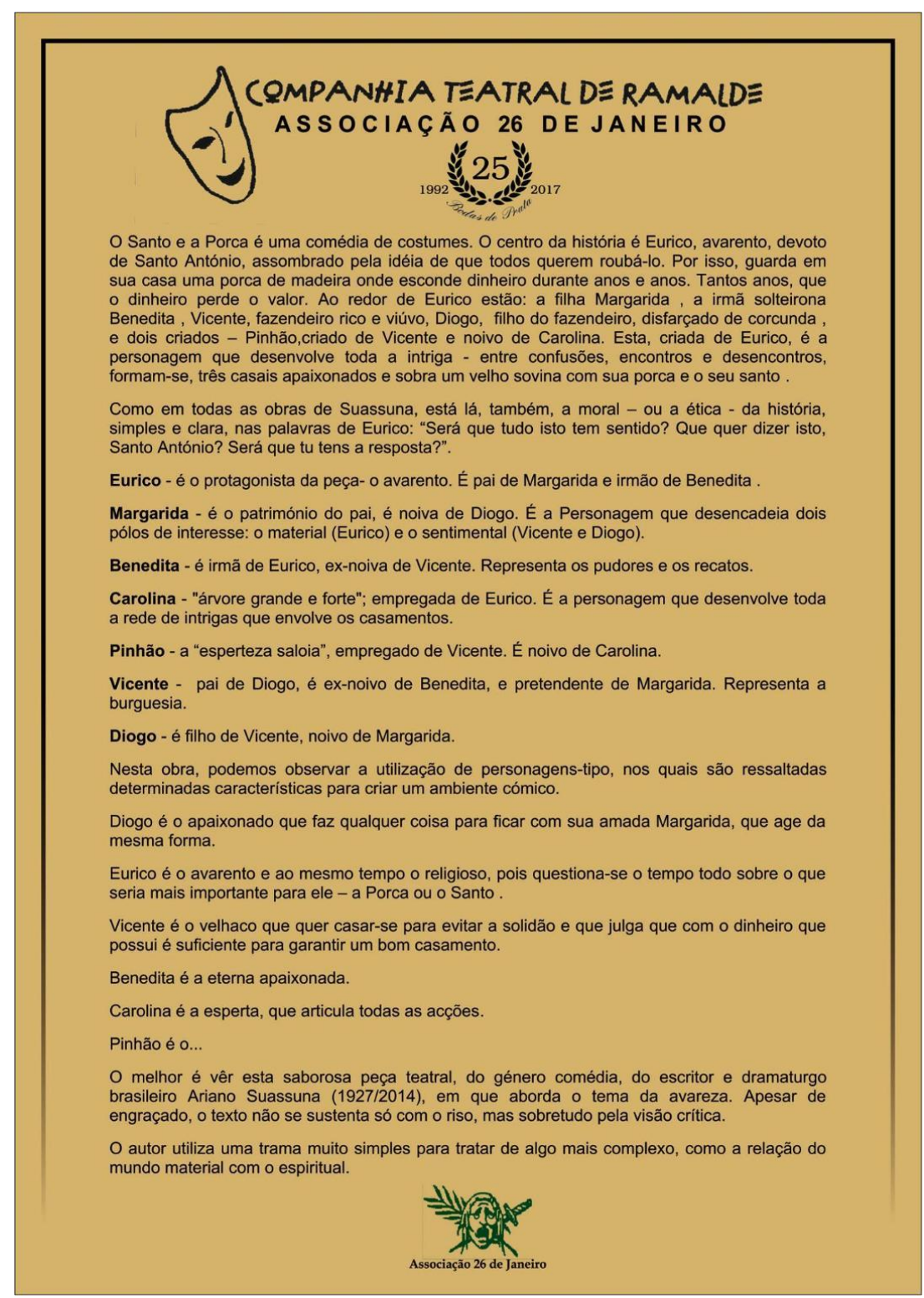



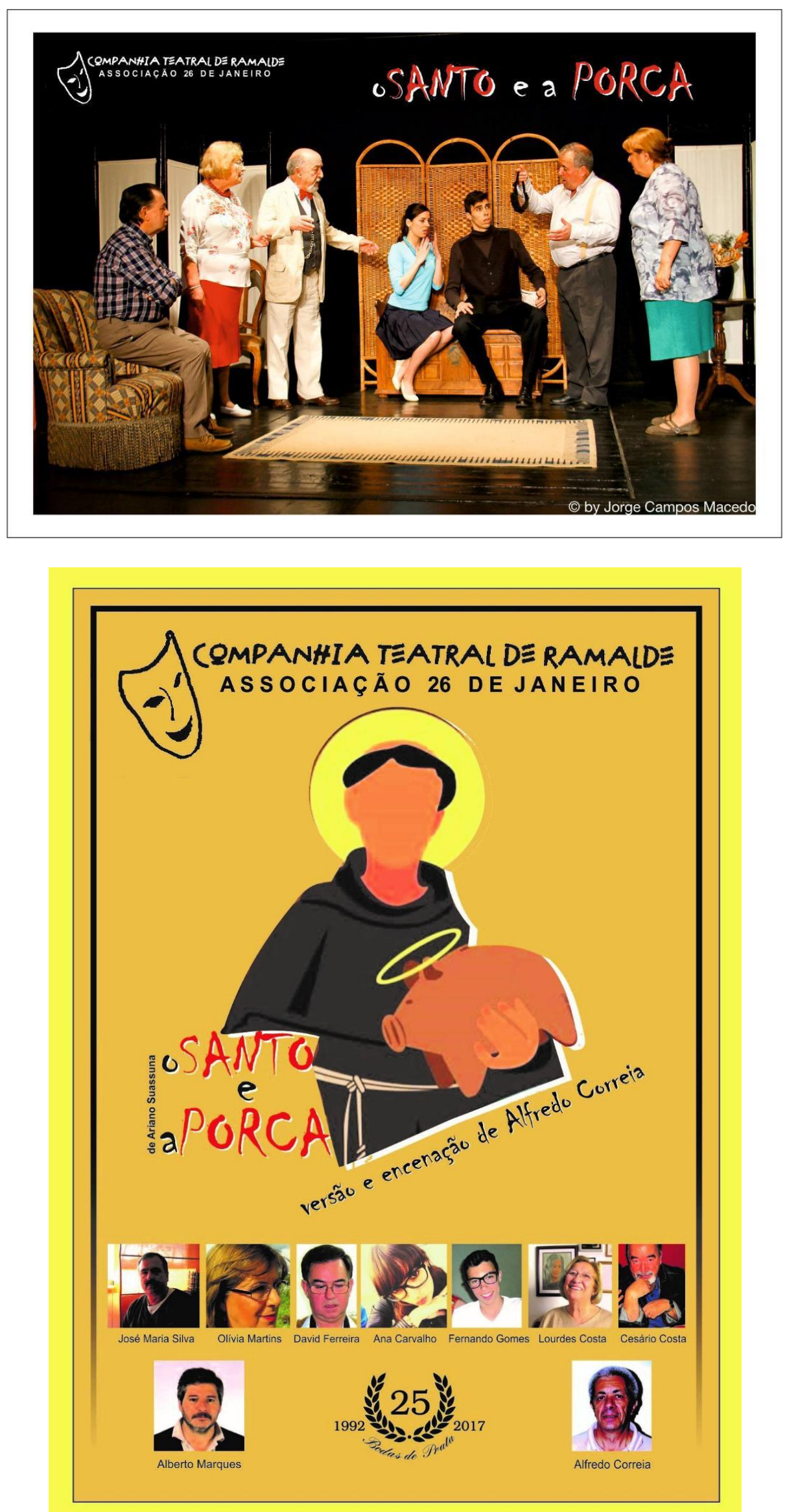


\section{Conclusão}

Pouco riscado pela Censura do Estado Novo, embora proibido mais pelas opções políticas das pessoas que o encenavam que por qualquer outro motivo, ou dando vitória a um grupo amador, mesmo durante o Estado Novo o Auto da Compadecida teve mais divulgação que O Santo e a Porca, apesar deste nunca ter recebido cortes ou proibições.

Apesar de eleito quase sempre para ser representado pelo teatro amador, talvez pelo seu cariz popular, o texto de Suassuna, nesses quase sessenta anos desde sua primeira apresentação em Portugal pelo Teatro Cacilda Becker, teve, pelo menos, catorze montagens diferentes, o que prova a sua vitalidade. E isso para não falar nas teses e dissertações que foram escritas sobre a obra suassuniana

\section{Referências}

A VOZ DE RIBEIRADIO. Ribeiradio, 1 de março de 1972.

BARATA, J. O. Máscaras da Utopia. história do Teatro Universitário em

Portugal. 1938-74. Lisboa: Fundação Calouste Gulbenkian. Serviço de Educação e Bolsas, 2009.

DIÁRIO DA MANHÃ. Lisboa, 15 out. 1959. . Lisboa, 19 out. 1959.

DIÁRIO DE NOTÍCIAS. Rio de Janeiro, 23 out. 1959.

GAZETA DAS CALDAS. Caldas da Rainha, 17 jul. 1962. . Caldas da Rainha, 25 jul. 1962. . Caldas da Rainha, 7 ago. 1962. . Caldas da Rainha, 9 out. 1962. . Caldas da Rainha, 16 out. 1962. 
GRALHEIRO, J. Teatro popular nas Beiras. A Aldraba, 2014. Disponível em:

$<$ http://aldrabaassociacao.blogspot.pt/2014/o4/teatro-popular-nas

beiras.html?showComment=1398166250531\&m=1\#c2488700421833515527>. Acesso em: 25 jul. 2017.

MASCARENHAS, D.; LIMA, L. Mestre Gil. Lisboa: [s. n.], 1967.

NOVIDADES. Lisboa, 22 out. 1959.

O SÉCULO. Lisboa, 1 out. 1962.

OSCAR, H. (sem título) In: SUASSUNA, Ariano. O Auto da Compadecida. Rio de Janeiro, Livraria Agir, 1957, p. 9-15.

PÚBLICO. Oito peças para uma vida. Entrevista de Ruy de Carvalho a Adelino

Gomes, 17 jul. 2007.

SUASSUNA, Ariano. O Auto da Compadecida. Rio de Janeiro, Livraria Agir, 1957.

Recebido em o6/10/2017.

Aprovado em 09/10/2017. 